\begin{tabular}{|l|l|l|l|l|l|} 
J. Tek. Ling & Vol.11 & No.3 & Hal. 451 - 457 & Jakarta, September 2010 & ISSN 1441-318X \\
\hline
\end{tabular}

\title{
KONSORSIA BAKTERI PENGURAI SIANIDA YANG DI ISOLASI DARI BUANGAN INDUSTRI PENGOLAHAN EMAS
}

\author{
Nunik Sulistinah dan Bambang Sunarko \\ Bidang Mikrobiologi, Pusat Penelitian Biologi-LIPI \\ Cibinong Science Center, JI Raya Jakarta-Bogor Km 46 \\ Cibinong 16911 \\ E-mail : bsun.biol@indo.ned.id
}

\begin{abstract}
Bacterial consortium capable of growing and utilizing cyanide as a source of nitrogen were isolated from effluent of gold mining industry. The isolation was conducted using liquid enrichment medium with potassium cyanide and glucose as nitrogen and carbon source, respectively. These consortium could tolerate and were able to grow on KCN at concentration of up to $1000 \mathrm{ppm}$. Bacterial consortium LP3 were also able to degrade potassium cyanide and ammonium as product of the degradation. The degradation rate was 9,0 $\mathrm{MM}$ per minute. The cyanide-degrading bacteria found in this consortium were identified as Bacillus, Corynebacterium, and Serratia.
\end{abstract}

Keywords: potassium cyanide, nitrogen source, bacterial consortium LP3, degradation

\section{PENDAHULUAN}

Senyawa sianida, organik maupun inorganik, tersebar luas di lingkungan karena banyak digunakan sebagai prekursor untuk produksi senyawa nitril, nilon, dan plastik. Selain itu, sianida juga digunakan dalam industri pelapisan logam (electroplating), industri pertambangan, dan juga industri karet sintetik ${ }^{4}$. Sianida merupakan senyawa yang sangat toksik ${ }^{3,7,11)}$ sehingga berpotensi sebagai pencemar lingkungan. Menurut Akcil (2002), secara global diperkirakan 2,5 juta ton sianida diproduksi setiap tahun ${ }^{5}$.

Sianidasi, yaitu proses pelarutan dan proses pemisahan emas dari larutannya dengan menggunakan senyawa $\mathrm{NaCN}$ atau $\mathrm{KCN}$, merupakan proses yang sangat penting dalam industri pertambangan emas (gold mining). Penggunaan sianida dalam industri ini dilaporkan hampir mencapai $90 \%$, suatu prosentase yang relatif cukup tinggi. Sebagai contoh setiap tahun, Turki membutuhkan sekitar 2500 ton sodium sianida untuk mengekstraksi bijih emas dan tembaga ${ }^{5)}$. Selain itu, konsentrasi sianida yang cukup tinggi dilaporkan juga dijumpai dalam luaran (effluent) dan limbah padat tailing dari industri penambangan/ pengolahan emas.

Detoksifikasi sianida dapat dilakukan antara lain melalui proses elektrolitis, ultrasonik, fotolitik, maupun proses biologis $^{15)}$.

Detoksifikasi secara biologis dinilai lebih menguntungkan dibandingkan dengan 
metode lain, karena lebih hemat energi dan biaya, detoksifikasi terjadi secara sempurna dan tidak menghasilkan produk yang toksik, sehingga lebih ramah lingkungan ${ }^{1)}$.

Beberapa mikroba, seperti Acidovorax facilis, Alcaligenes faecalis, Arthrobacter, Bacillus, Micrococcus, Neisseria, Pseudomonas, dan Thiobacillus dilaporkan mampu mengoksidasi sianida anorganik ${ }^{6,19)}$. Selain sebagai pendegradasi senyawa sianida, sel bakteri juga dilaporkan dapat digunakan sebagai absorbant untuk mengikat sianida yang terkandung dalam limbah pengolahan emas. Dalam operasi pertambangan komersial, mikroba juga dimanfaatkan sebagai sarana biobleaching bijih tembaga, uranium dan emas ${ }^{18)}$.

Meskipun demikian, sampai saat ini penelitian yang terkait dengan detoksifikasi sianida masih sangat sedikit dilakukan di Indonesia. Tujuan penelitian ini adalah untuk menguji kemampuan tumbuh berbagai isolat bakteri yang diisolasi dari effluent pengolahan emas. Dari penelitian ini diharapkan diperoleh beberapa isolat yang mampu mendegradasi senyawa sianida, khususnya sianida anorganik, sehingga dapat digunakan sebagai informasi untuk penelitian selanjutnya, khususnya penanganan limbah sianida.

\section{BAHAN DAN METODE}

\subsection{Mikroorganisme}

Mikroba yang digunakan dalam penelitian ini berupa konsorsia bakteri LP3 yang diisolasi dari limbah/luaran industri pengolahan emas PT ANTAM di CikotokBanten. Genus bakteri yang ditemukan dalam konsorsia tersebut adalah Corynebacterium, Serratia, and Bacillus.

\subsection{Media kultivasi mikroba pengurai sianida}

Media yang digunakan untuk menumbuhkan konsorsia bakteri LP3 adalah media mineral ${ }^{16,17)}$. Sebagai sumber karbon digunakan $50 \mathrm{mM}$ glukosa dan sebagai sumber nitrogen digunakan 600 ppm KCN.

\subsection{Penentuan pertumbuhan konsorsia bakteri LP3.}

Pola pertumbuhan konsorsia bakteri LP3 dilakukan dengan menumbuhkan konsorsia tersebut dalam $100 \mathrm{ml}$ Erlenmeyer berisi $50 \mathrm{ml}$ media mineral yang mengandung 600 ppm KCN. Kultur mikroba selanjutnya diinkubasi di atas mesin pengocok (shaker) pada suhu kamar $\left(28^{\circ} \mathrm{C}\right)$ selama 72 jam. Pertumbuhan ditentukan dengan menggunakan satuan kerapatan optik pada panjang gelombang $436 \mathrm{~nm}$.

\subsection{Pengaruh konsentrasi $\mathrm{KCN}$ terhadap pertumbuhan konsorsia bakteri LP3}

Pengujian pengaruh konsentrasi KCN terhadap pertumbuhan isolat bakteri LP3 dilakukan dengan cara menumbuhkan konsorsia tersebut pada media mineral yang mengandung $\mathrm{KCN}$ dalam berbagai konsentrasi $(0,400,600,800$, dan 1000 ppm). Pertumbuhan diamati dengan mengukur kerapatan optik kultur pada panjang gelombang $436 \mathrm{~nm}$.

\subsection{Penentuan konsentrasi sianida.}

Penentuan konsentrasi sianida selama proses pertumbuhan bakteri dilakukan secara kolorimetri9 ${ }^{9}$. Konsentrasi sianida dalam supernatan sampel dihitung berdasarkan kurva standar.

\subsection{Penentuan konsentrasi amonium}

Konsentrasi amonium ditentukan secara kolorimetri dengan menggunakan metode Nessler ${ }^{9}$. Konsentrasi amonium dalam supernatan sampel dihitung berdasarkan kurva standar. 


\subsection{Penentuan pola degradasi $\mathrm{KCN}$ oleh konsorsia bakteri LP3}

Penentuan pola degradasi $\mathrm{KCN}$ dilakukan dengan cara menumbuhkan konsorsia bakteri LP3 pada media mineral yang mengandung 600 ppm KCN (sebagai sumber nitrogen) dan $50 \mathrm{mM}$ glukosa (sebagai sumber karbon). Dalam selang waktu 24 jam, $10 \mathrm{ml}$ sampel diambil untuk penentuan konsentrasi KCN dan $\mathrm{pH}$ selama pertumbuhan.

\subsection{Produksi biomassa sel}

Biomassa sel diproduksi dalam Erlenmeyer $(1000 \mathrm{ml})$, berisi $500 \mathrm{ml}$ media pertumbuhan yang mengandung 600 ppm $\mathrm{KCN}$ dan diinkubasi pada suhu kamar $( \pm 28$ $\left.{ }^{\circ} \mathrm{C}\right)$. Sel dipanen pada waktu pertumbuhan optimum (72 jam) dengan cara mensentrifuse kultur tersebut dengan kecepatan 10.000 rpm, selama 15 menit pada suhu $4{ }^{\circ} \mathrm{C}$. Pelet yang diperoleh dicuci dengan 50 $\mathrm{mM}$ Tris/buffer HCL $(\mathrm{pH} 8,5)$ sebanyak 2 kali, supernatan kemudian dibuang dan pelet dikumpulkan. Pelet yang diperoleh digunakan untuk penentuan karakteristik enzim dalam sel utuh.

\subsection{Degradasi $\mathrm{KCN}$ dengan menggunakan konsorsia bakteri LP3}

Degradasi $\mathrm{KCN}$ dilakukuan dengan cara menambahkan $5 \%(\mathrm{~b} / \mathrm{v})$ sel kedalam $50 \mathrm{mM}$ buffer Tris $\mathrm{HCl}(\mathrm{pH} 8,5)$ yang mengandung 1000 ppm KCN. Campuran reaksi tersebut kemudian diinkubasi di atas mesin pengocok pada suhu kamar $\left( \pm 28^{\circ} \mathrm{C}\right)$. Dalam interval waktu tertentu, contoh diambil dan kemudian disentrifuse. Kadar $\mathrm{NH}_{4}^{+}$dalam supernatan ditentukan dengan metode Nessler ${ }^{12)}$, sedangkan konsentrasi sianida ditentukan dengan metode kolorimetri.

\section{HASIL DAN PEMBAHASAN}

Secara umum dapat ditunjukkan bahwa, konsorsia bakteri LP3 mampu tumbuh dan memanfaatkan KCN sebagai sumber nitrogen, hingga mencapai konsentrasi 1000 ppm ( \pm 15 mM) (Gambar 1). Dibandingkan Bulkholderia cepacia C-3, pertumbuhan LP3 relatif lebih rendah, karena $B$. cepacia C-3 mampu tumbuh pada $\mathrm{KCN}$ hingga konsentrasi $25 \mathrm{mM}^{2}$ ). Selain pada $\mathrm{KCN}$, isolat bakteri ini juga mampu memanfaatkan potasium sianat, potasium tiosianat, linamarin, alifatik dan aromatik nitril sebagai substrat pertumbuhannya.

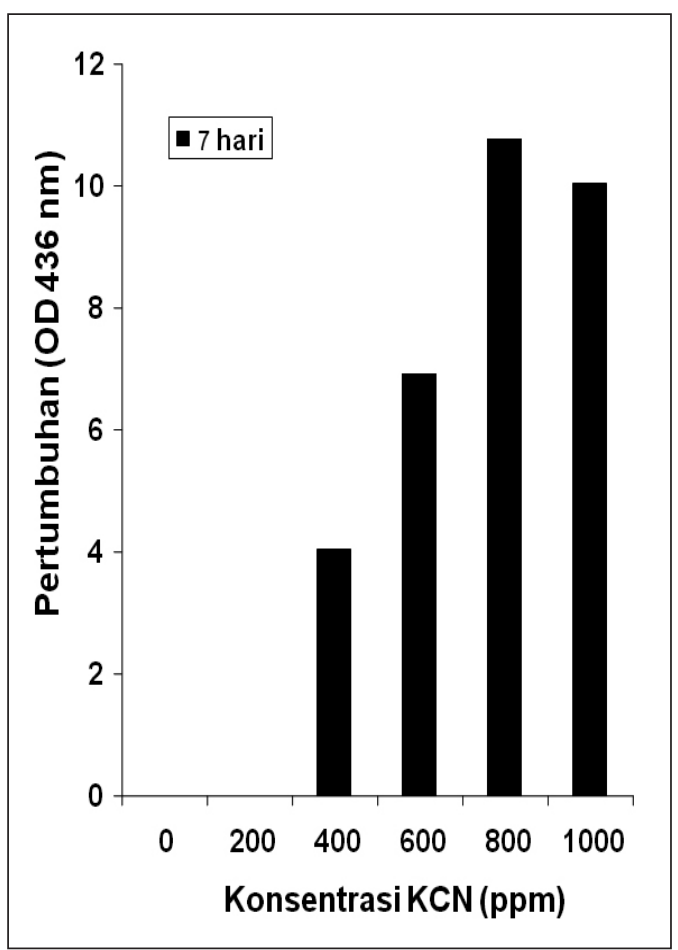

Gambar 1. Pertumbuhan Konsorsia Bakteri LP3 Pada Berbagai Konsentrasi KCN

Dari Gambar 1 tampak bahwa pertumbuhan konsorsia bakteri LP3 semakin baik dengan meningkatnya konsentrasi KCN. Pertumbuhan tertinggi dicapai pada konsentrasi 800 ppm. Namun demikian, LP3 hanya mampu tumbuh bila senyawa KCN digunakan sebagai sumber nitrogen saja. 
Bila KCN digunakan sebagai satu-satunya sumber karbon, energi dan nitrogen, LP3 tak mampu tumbuh dalam senyawa tersebut (data tidak ditampilkan).

Kemampuan tumbuh konsorsia bakteri LP3 pada KCN merupakan indikasi awal, bahwa LP3 mampu mensintesis enzim sianidase, yaitu enzim yang mampu mendegradasi sianida menjadi amonia dan asam format ${ }^{14,20)}$. Kemampuan yang sama juga ditunjukkan oleh Pseudomonas sp, yang diisolasi dari limbah kilang minyak. Namun, dibandingkan dengan Pseudomonas ini, pertumbuhan konsorsia bakteri LP3 pada $\mathrm{KCN}$ relatif lebih baik. Beberapa spesies Pseudomonas dilaporkan juga mampu mengoksidasi sianida dan thiosianat ${ }^{6,13}$. Dalam mendegradasi senyawa sianida, Pseudomonas fluorescens, Pseudomonas pseudoalcaligenes melibatkan beberapa enzim pendegradasi sianida, seperti oksigenase, sianida nitrilase, dan sianida hidratase (Kao et al., 2003).

Pola pertumbuhan konsorsia bakteri LP3, perubahan $\mathrm{pH}$ dan konsentrasi substrat (KCN) selama pertumbuhan ditampilkan pada Gambar 2A. Dalam gambar tersebut tampak, bahwa selama pertumbuhan LP3, konsentrasi substrat (KCN) dan $\mathrm{pH}$ terus menurun. Walaupun dalam kontrol (Gambar 2B) terjadi pula penurunan konsentrasi substrat (KCN), namun penurunannya tidak sebesar dalam media pertumbuhan (Gambar 2A). Selain itu, nilai pH medium dalam kontrol tidak mengalami perubahan yang berarti, selama masa inkubasi. Atas dasar ini, maka penurunan $\mathrm{pH}$ medium dan konsentrasi substrat selama pertumbuhan konsorsia bakteri LP3 dapat dilihat sebagai indikasi terjadinya proses degradasi KCN oleh LP3 dan/atau aktivitas enzim pendegradasi senyawa tersebut.

Selama inkubasi ( \pm 140 jam), konsentrasi substrat $(\mathrm{KCN})$ turun sebesar 0,127 $\mathrm{mM}( \pm$ $98 \%$ ), sedangkan dalam kontrol, dalam waktu yang sama, konsentrasi substrat menurun sebesar $1,517 \mathrm{mM}( \pm 80 \%)$. Ini berarti, penurunan konsentrasi KCN akibat aktivitas biologis adalah sebesar 1,39 mM, dengan laju degradasi sebesar 0,0096 mM/jam.

Secara umum, biodegradasi senyawa sianida dilaporkan melalui satu atau dua tahapan reaksi. Pada satu tahapan reaksi, $\mathrm{HCN}$ dikonversi secara langsung menjadi amonia dan asam format sebagai produk akhirnya dengan melibatkan enzim sianidase, sedangkan konversi melalui 2 tahapan reaksi melibatkan enzim sianida hidratase dengan menghasilkan senyawa amida (formamida) sebagai senyawa intermediet. Kemudian formamida dikonversi menjadi amonia dan asam format oleh formamide hydrolase (Reilly\&Turner, 2003, Almagro et al., 2005, Huertas et al., 2006). Dilaporkan bahwa strain dari Alcaligenes denitrificans mengkonversi senyawa sianida secara langsung menjadi asam format dan amonia (Dumestre et al., 1997).

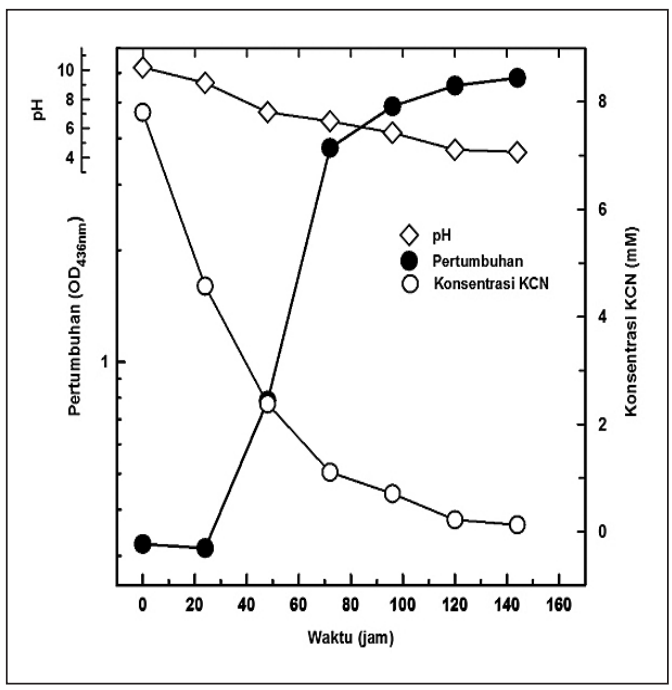

Gambar 1. (A). Pola pertumbuhan konsorsia bakteri LP3, perubahan $\mathrm{pH}$ dan konsentrasi $\mathrm{KCN}$ selama pertumbuhan pada $600 \mathrm{ppm} \mathrm{KCN}$; (B). Kontrol (media tumbuh tanpa LP3)

Dalam proses degradasi $\mathrm{KCN}$ dengan menggunakan sel utuh konsorsia bakteri LP3 (Gambar 3A) terjadi penurunan substrat $(\mathrm{KCN})$, yang diikuti dengan pembentukan 


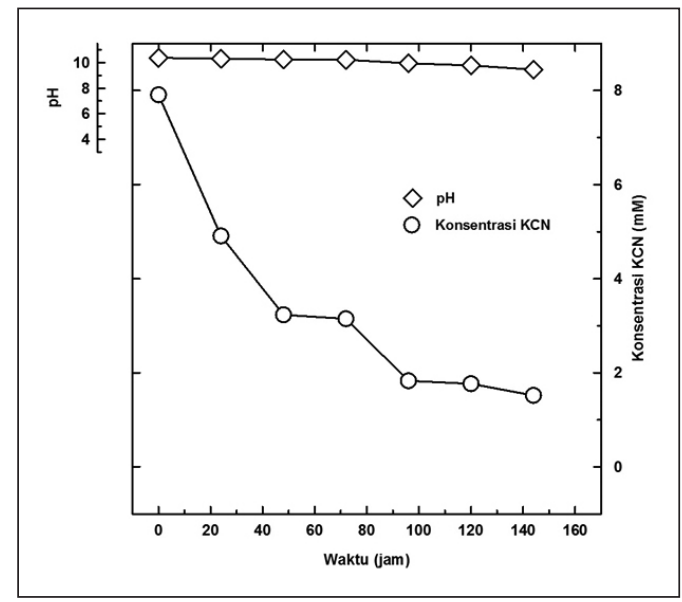

Gambar 2. (A). Pola pertumbuhan konsorsia bakteri LP3, perubahan $\mathrm{pH}$ dan konsentrasi $\mathrm{KCN}$ selama pertumbuhan pada $600 \mathrm{ppm} \mathrm{KCN}$; (B). Kontrol (media tumbuh tanpa LP3)

produk degradasi $\left(\mathrm{NH}_{4}^{+}\right)$. Walaupun dalam kontrol (Gambar 3B), terjadi pula penurunan substrat $(\mathrm{KCN})$, namun produk degradasi berupa $\mathrm{NH}_{4}{ }^{+}$tidak teridentifikasi. Dari hasil ini dapat diinterpretasikan, bahwa sel LP3 mampu mendegradasi KCN. Ini berarti, LP3 mampu mensintesis enzim pendegradasi sianida.

Selama inkubasi 180 menit, degradasi $\mathrm{KCN}$ dengan sel LP3 hanya mampu menurunkan konsentrasi $\mathrm{KCN}$ sebesar $2,88 \mathrm{mM}( \pm 20 \%)$, sedangkan dalam kontrol, dalam waktu yang sama, konsentrasi substrat menurun sebesar 2,34 mM $( \pm 15$ $\%)$. Ini berarti, penurunan konsentrasi KCN akibat proses biodegradasi adalah sebesar $0,54 \mathrm{mM}$, dengan laju degradasi sebesar $0,003 \mathrm{mM} / \mathrm{menit}$. Bila dihitung berdasarkan pembentukan produk degradasinya, laju degradasi $\mathrm{KCN}$ adalah sebesar 0,009 mM/ menit. Konsorsia bakteri LP3 teridentifikasi sebagai genus Bacillus, Corynebacterium, dan Serratia (Supartono)

\section{KESIMPULAN}

Dari penelitian ini dapat dibuktikan bahwa konsorsia bakteri LP3 mampu
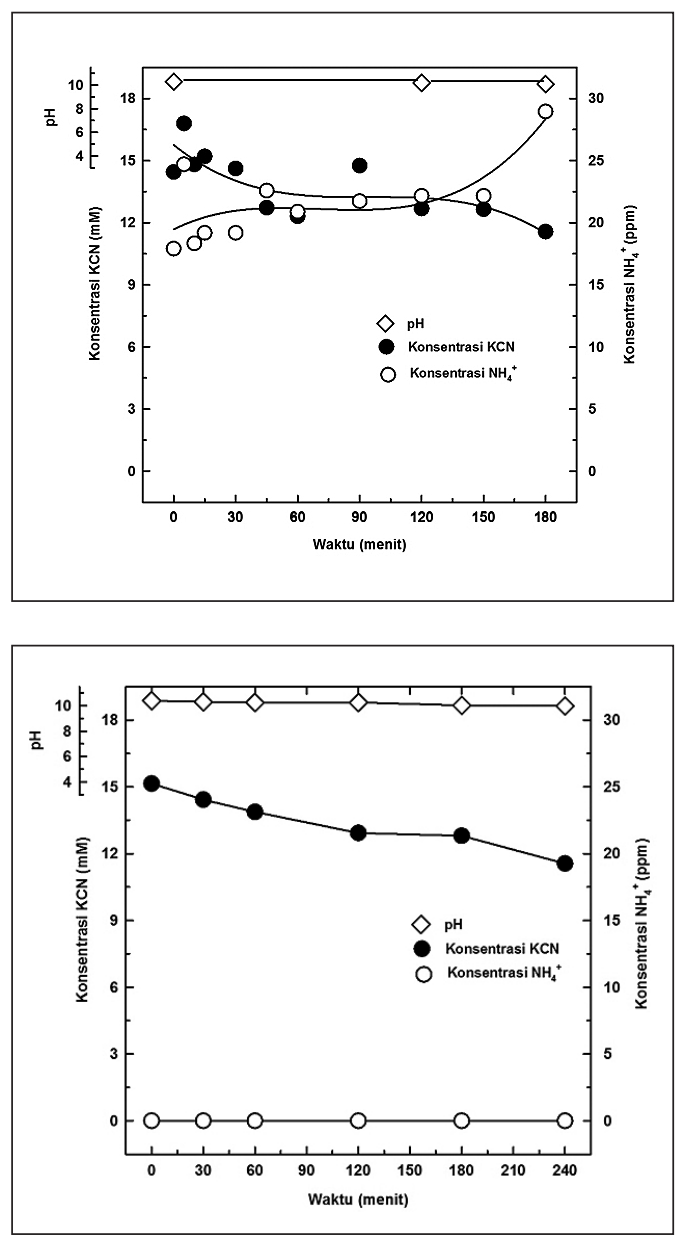

Gambar 3. (A). Pola degradasi KCN dengan menggunakan sel utuh (whole cell) konsorsia bakteri LP3; (B). Kontrol (media tumbuh mengandung KCN, tanpa penambahan sel)

tumbuh dan memanfaatkan potasium sianida (KCN) sebagai sumber nitrogen, sampai dengan konsentrasi 1000 ppm. Selain itu, LP3 terbukti juga mampu mendegradasi $\mathrm{KCN}$, dengan ammonium sebagai salah satu produk degradasinya. Hal ini mengindikasikan, bahwa konsorsia bakteri LP3 mampu mensintesis enzim pendegradasi sianida, meskipun aktivitas enzim tersebut kemungkinannya sangat rendah. Laju degradasi KCN dengan sel utuh sebesar $0,009 \mathrm{mM} /$ menit. 


\section{UCAPAN TERIMA KASIH}

Penulis mengucapkan terima kasih kepada Pusat Penelitian Biologi-LIPI melalui anggaran DIPA 2008 yang telah mendanai penelitian ini.

\section{DAFTAR PUSTAKA}

1. Adams, DJ., Komea, JV., Pickett, TM. 2001. Biological cyanide degradation . in Young, C (Ed.), Cyanide: Social, Industrial and Economic Aspects. The Metal Society, Warrendale, PA., pp. 203-213

2. Adjei, M.D. \& Yoshiyuki, O.1999. Isolation and characterization of cyanide-utilizing Burkholderia cepacia strain C-3. World Journal of Microbiology and Biotechnology, Vol. 15 (6) :

3. Akcil, A., Karahan, A.G., Ciftci, H \& Sagdic, O. 2003. Biological treatment of cyanide by natural isolated bacteria (Pseudomonas $\mathrm{sp}$ ). Minerals Engineering 16 : 643-649

4. Akcil, A. 2003. Destruction of cyanide in gold mill effluents : Biological versus chemical treatments. Biotechnology Advances 21 : 501-511

5. Akcil, A. 2002. First application of cyanidation process in Turkish gold mining and its environmental impacts. Mineral Engineering 15 : 695-699

6. Akcil, A \& Mudder, T. 2003. Microbial destruction of cyanide wastes in gold mining : process review. Biotechnology Letters 25 : 445-450

7. Almagro, VML., Huertas MJ., Luque, MM., Vivian, CM., Roldan, MD., Gil, LJG., Castillo, F., and Blasco, R. 2005. Bacterial Degradation of Cyanide and Its Metal Complexes under Alkaline
Conditions. Applied and Environmental Microbiology, 15(6) : 940-947

8. Almagro, VML., Huertas MJ., Luque, MM., Vivian, CM., Roldan, MD., Gil, LJG., Castillo, F., and Blasco, R. 2005. Alkaline cyanide biodegradation by Pseudomonas pseudoalkaligenes CECT5344. Biochemical Society, Vol. 33 (part 1) : 168-169.

9. Arnold . 1992. Standard Methods For the Examination of Water and Wastewater $18^{\text {th }}$ edition

10. Dumestre,A., Therese, C., Jean-Marie, P., Mylene, G., \& Jacques, B. 1997. Cyanide Degradation under Alkaline Conditions by a Strain of Fusarium solani Isolated from Contaminated Soils. Applied and Environmental Microbiology, Vol. 63(7) : 2729-2734.

11. Fargundes, EMS., LH. Rosa, NCM. Gomes, MH. Santos, PF. Pimentel. 2004. Thiocyanate Degradation by Pure and Mixed Cultures of Microorganisms. Brazillian Journal of Microbiology, 35 : 333-336

12. Gerhardt, P. \& Drew, SW. 1994. Liquid Culture. In : Gerhardt, P., Murray, R.G.E., Wood, WA. \& Krieg, N.R. (eds). Methods for General and Molecular Bacteriology. ASM., Washington, DC., 248-277

13. Huertas, M.J., VML. Almagro, M.M. Luque, R. Blascot, CM. Vivian and F. Castillo. 2006. Cyanide metabolism of Pseudomonas pseudoalkaligenes CECT5344: role of siderophores. Biochemical Society Transactions, Vol.34 (part 1) : 152-155.

14. Ingvorsen, K., Hojer-Pedersen, B. \& Godtfredsen, SE. 1991. Novel cyanidehydrolyzing enzyme from Alcaligenes 
xylosoxidans subsp. Denitrificans. Applied and Environmental Microbiology 57, 1783-1789

15. Kitis, M., Karakaya, E., Yigit, N.O.,Civelekoglu, G. \& Akcil, A. 2005. Heterogenous catalytic degradation of cyanide using copper-impregnated and hydrogen peroxide. Water Research 39 : 1652-1662.

16. Meyer, O \& Schlegel HG. 1983. Biology of Aerobic Carbon Monoxide Oxidizing Bacteria. Annual Review Microbiology 37 : 277-310

17. Pfennig, N. 1974. Rhodopseudomonas globiformis sp.n., A new species of the Rhodospirillaceae. Arch. Microbiology $100: 197-206$
18. Rawling, D.E. \& Silver, S. 1995. Mining with Microbes. Nature Biotechnology, p :2-5

19. Reilly, C.O. \& Turner, P.D. 2003. The nitrilase family of $\mathrm{CN}$ hydrolysing enzymes-a comparative study. Journal of Applied Microbiology 95 :1161-1174

20. Watanabe, A., Kazuyoshi, Y., Kazunori, I. \& Isao, K. 1998. Cyanide hydrolisis in cyanide-degrading bacterium : Pseudomonas stutzeri AK61 by cyanidase. Microbiology, 144 : 1677-1682 